\title{
Xanthine Oxidase Inhibitory Activity of Vietnamese Medicinal Plants
}

\author{
Mai Thanh Thi Nguyen, Suresh Awale, Yasuhiro Tezuka, Quan Le Tran, Hiroshi Watanabe, and \\ Shigetoshi KADOTA* \\ Institute of Natural Medicine, Toyama Medical and Pharmaceutical University; 2630-Sugitani, Toyama 930-0194, Japan. \\ Received March 26, 2004; accepted June 7, 2004
}

\begin{abstract}
Among 288 extracts, prepared from 96 medicinal plants used in Vietnamese traditional medicine to treat gout and related symptoms, 188 demonstrated xanthine oxidase (XO) inhibitory activity at $100 \mu \mathrm{g} / \mathrm{ml}$, with 46 having greater than $50 \%$ inhibition. At $50 \mu \mathrm{g} / \mathrm{ml}, 168$ of the extracts were active, with 21 possessing more than $50 \%$ inhibition. At $25 \mu \mathrm{g} / \mathrm{ml}, 146$ extracts exhibited inhibitory activity, with 8 showing over $50 \%$ inhibition, while 126 extracts presented activity at $10 \mu \mathrm{g} / \mathrm{ml}$, with 2 having greater than $50 \%$ inhibition. The MeOH extracts of Artemisia vulgaris, Caesalpinia sappan (collected at the Seven-Mountain area), Blumea balsamifera (collected in Lam Dong province), Chrysanthemum sinense and $\mathrm{MeOH}-\mathrm{H}_{2} \mathrm{O}$ extract of Tetracera scandens (Khanh Hoa province) exhibited strong XO inhibitory activity with $\mathrm{IC}_{50}$ values less than $20 \mu \mathrm{g} / \mathrm{ml}$. The most active extract was the $\mathrm{MeOH}$ extract of the flower of $C$. sinense with an $\mathrm{IC}_{50}$ value of $5.1 \mu \mathrm{g} / \mathrm{ml}$. Activity-guided fractionation of the $\mathrm{MeOH}$ extract led to the isolation of caffeic acid (1), luteolin (2), eriodictyol (3), and 1,5-di-O-caffeoylquinic acid (4). All these compounds showed significant XO inhibitory activity in a concentration-dependent manner, and the activity of 2 was more potent $\left(\mathrm{IC}_{50} 1.3 \mu \mathrm{M}\right)$ than the clinically used drug, allopurinol ( $\left.\mathrm{IC}_{50} 2.5 \mu \mathrm{M}\right)$.
\end{abstract}

Key words Vietnamese medicinal plant; xanthine oxidase inhibitory activity; gout; Chrysanthemum sinense

Natural products are excellent sources of lead compounds in the search for new medicaments for the treatment of diseases. The largest present underexplored source of such materials lies in tropical and subtropical regions of the world. In these areas, a long tradition of ethnobotanical medicine often exists and offers a rich and relatively untapped source for the discovery of new drugs from natural products. Vietnam, a tropical Southeast Asian country, also has a long history of traditional medicine systems. ${ }^{1)}$ However, systematic exploitation of these natural resources for their human health benefits has not been carried out to a significant degree.

Gout is a common disease with a worldwide distribution. Hyperuricemia, which is associated with gout, results from the overproduction or underexcretion of uric acid and is greatly influenced by a high dietary intake of foods rich in nucleic acids, such as meats (especially organ meats), leguminous seeds, some types of seafood, and food yeasts. ${ }^{2,3)}$ During the last step of purine metabolism, xanthine oxidase (XO) catalyses the oxidation of xanthine and hypoxanthine into uric acid. $\left.{ }^{4}\right)$ Uricosuric drugs which increase the urinary excretion of uric acid, or XO inhibitors which block the terminal step in uric acid biosynthesis, can lower the plasma uric acid concentration, and are generally employed for the treatment of gout. ${ }^{5)}$ Allopurinol is a clinically used XO inhibitor in the treatment of gout, but this drug suffers from many side effects such as hepatitis, nephropathy, and allergic reactions. $\left.{ }^{6}\right)$ Thus, new alternatives with increased therapeutic activity and less side effects are desired. Moreover, superoxide anion radicals generated by XO are involved in various pathological states such as hepatitis, inflammation, ischemiareperfusion, carcinogenesis, and aging.,7) Thus, the search for novel XO inhibitors would be beneficial not only to treat gout but also to combat various other diseases.

To identify potential XO inhibitory agents from natural sources, we have tested 288 extracts prepared from 96 selected medicinal plants, which are used by the indigenous people in Vietnam for the treatment of gout or diseases asso- ciated with symptoms such as rheumatism, arthritis and inflammation. In addition, the active constituents of Chrysanthemum sinense, which showed the most potent $\mathrm{XO}$ inhibitory activity, have been determined.

\section{MATERIALS AND METHODS}

Plant Materials Vietnamese medicinal plants used in this study were collected at the Seven-Mountain area in An Giang province on March 1998, Lam Dong province in May 1998 and November 2001, Khanh Hoa province in November 2002, and Phu Yen province in November 2002 (Table 1). The plants collected at the Seven-Mountain area were identified by Prof. Le Cong Kiet, Department of Botany, University of Ho Chi Minh City, Ho Chi Minh City, Vietnam, while other plants were identified by Mr. Nguyen Duy Chinh, Department of Resource and Environment, Dalat University, Dalat City, Lam Dong province, Vietnam. The voucher specimens are preserved at the Museum of Materia Medica, Research Center for Ethnomedicines, Institute of Natural Medicine, Toyama Medical and Pharmaceutical University, Toyama, Japan.

Chemicals Xanthine oxidase (EC 1.2.3.2) from bovine milk (10 units $/ \mathrm{ml}$ ) and xanthine were obtained from Sigma Chemical Co. (St. Louis, MO, U.S.A.). Allopurinol was purchased from Wako Pure Chemical Industries, Ltd. (Osaka, Japan). Other reagents were of the highest grade available.

Preparation of Samples Each medicinal plant (10 $213 \mathrm{~g}$ ) was cut into small pieces and extracted successively with $\mathrm{MeOH}(200-300 \mathrm{ml}$, reflux, $2 \mathrm{~h}, \times 3), \mathrm{MeOH}-\mathrm{H}_{2} \mathrm{O}$ $(1: 1,200-300 \mathrm{ml}$, reflux, $2 \mathrm{~h}, \times 2)$, and water $(200$ $300 \mathrm{ml}$, reflux, $2 \mathrm{~h}$ ). The $\mathrm{MeOH}$ solution was evaporated under reduced pressure to give a $\mathrm{MeOH}$ extract, while $\mathrm{MeOH}-\mathrm{H}_{2} \mathrm{O}(1: 1)$ and water solutions were concentrated under reduced pressure and lyophilized to give $\mathrm{MeOH}-\mathrm{H}_{2} \mathrm{O}$ ( $1: 1)$ and $\mathrm{H}_{2} \mathrm{O}$ extracts, respectively.

Assay of XO Activity The XO inhibitory activity was 
assayed spectrophotometrically under aerobic conditions, based on the procedure reported by Noro et al., ${ }^{8)}$ with modification by using 96-well plates. The assay mixture consisting of $50 \mu \mathrm{l}$ of test solution, $35 \mu \mathrm{l}$ of $70 \mathrm{~mm}$ phosphate buffer $(\mathrm{pH}=7.5)$, and $30 \mu \mathrm{l}$ of enzyme solution $(0.01$ units $/ \mathrm{ml}$ in $70 \mathrm{~mm}$ phosphate buffer, $\mathrm{pH}=7.5$ ) was prepared immediately before use. After preincubation at $25^{\circ} \mathrm{C}$ for $15 \mathrm{~min}$, the reaction was initiated by the addition of $60 \mu \mathrm{l}$ of substrate solution $(150 \mu \mathrm{M}$ xanthine in the same buffer). The assay mixture was incubated at $25^{\circ} \mathrm{C}$ for $30 \mathrm{~min}$. The reaction was stopped by adding $25 \mu \mathrm{l}$ of $1 \mathrm{~N} \mathrm{HCl}$, and the absorbance at $290 \mathrm{~nm}$ was measured with a Perkin-Elmer HTS-7000 Bio Assay Reader (Norwalk, CT, U.S.A.). A blank was prepared in the same way, but the enzyme solution was added to the assay mixture after adding $1 \mathrm{~N} \mathrm{HCl}$. One unit of $\mathrm{XO}$ is defined as the amount of enzyme required to produce $1 \mu \mathrm{mol}$ of uric $\operatorname{acid} / \mathrm{min}$ at $25^{\circ} \mathrm{C}$.

XO inhibitory activity was expressed as the percentage inhibition of $\mathrm{XO}$ in the above assay system, calculated as $(1-B / A) \times 100$, where $A$ and $B$ are the activities of the enzyme without and with test material. $\mathrm{IC}_{50}$ values were calculated from the mean values of data from four determinations.

The crude extracts were dissolved initially in DMSO followed by dilution with the buffer; the final concentration of DMSO was less than $0.25 \%$. Allopurinol, a known inhibitor of $\mathrm{XO}$, was used as a positive control.

Extraction and Isolation of the Active Compounds from the Flower of Chrysanthemum sinense Dried flower $(10.7 \mathrm{~g})$ of $C$. sinense was extracted with $\mathrm{MeOH}(300 \mathrm{ml}$, $\times 3)$ under reflux for $2 \mathrm{~h}$, to yield a $\mathrm{MeOH}$ extract $\left(1.4 \mathrm{~g} ; \mathrm{IC}_{50}\right.$ value, $5.06 \mu \mathrm{g} / \mathrm{ml})$. The $\mathrm{MeOH}$ extract $(650 \mathrm{mg})$ was chromatographed on silica gel with a $\mathrm{MeOH}-\mathrm{CHCl}_{3}$ solvent system to give six fractions: fr. $1\left(107 \mathrm{mg} ; \mathrm{IC}_{50},>100 \mu \mathrm{g} / \mathrm{ml}\right)$, fr. $2\left(152 \mathrm{mg} ; \mathrm{IC}_{50},>100 \mu \mathrm{g} / \mathrm{ml}\right)$, fr. $3\left(49.6 \mathrm{mg} ; \mathrm{IC}_{50}\right.$, $1.3 \mu \mathrm{g} / \mathrm{ml})$, fr. $4\left(49.6 \mathrm{mg}\right.$; $\left.\mathrm{IC}_{50}, 6.3 \mu \mathrm{g} / \mathrm{ml}\right)$, fr. 5 (49.6 mg; $\left.\mathrm{IC}_{50}, 11.9 \mu \mathrm{g} / \mathrm{ml}\right)$, fr. $6\left(49.6 \mathrm{mg} ; \mathrm{IC}_{50}, 78.8 \mu \mathrm{g} / \mathrm{ml}\right)$. Fraction 3 was separated by reversed-phase preparative TLC with $\mathrm{CH}_{3} \mathrm{CN}-\mathrm{MeOH}-\mathrm{H}_{2} \mathrm{O}(1: 1: 2)$ to give caffeic acid ${ }^{2)}$ (1, $3.6 \mathrm{mg})$ and luteolin ${ }^{9)}(\mathbf{2}, 4.9 \mathrm{mg})$. Fraction 4 was separated by reversed-phase preparative TLC with $\mathrm{CH}_{3} \mathrm{CN}-\mathrm{MeOH}-$ $\mathrm{H}_{2} \mathrm{O}(1: 1: 2)$ to give eriodictyol ${ }^{10)}(3,1.7 \mathrm{mg})$, while fraction 5 was subjected to reversed-phase preparative TLC with acetone- $\mathrm{CH}_{3} \mathrm{CN}-\mathrm{H}_{2} \mathrm{O}(2: 2: 7)$ to give 1,5 -di-O-caffeoylquinic $\operatorname{acid}^{11)}(4,6.4 \mathrm{mg})$. Their structures were identified by spectral analysis and comparison of their data with those in the literature.

\section{RESULTS AND DISCUSSION}

Xanthine oxidase (XO) is an enzyme that has been investigated for decades. Natural XO inhibitors were reported from a variety of plants used in traditional herbal medicines for the treatment of gout and rheumatism in China, ${ }^{12}$ Australia, ${ }^{13}$ North America, ${ }^{3)}$ Chile, ${ }^{14)}$ Paraguay, ${ }^{15)}$ and Panama. ${ }^{16)}$ Vietnam, a country possessing a long history of traditional medicine system, also has a number of medicinal plants used for gout and rheumatism, but no systematic investigations have been reported until now. In the present study, 96 plants from Vietnam were selected based on their ethnomedical use for the treatment of rheumatism, arthritis, and gout by the natives of this region (Table 1) and were successively extracted with $\mathrm{MeOH}, \mathrm{MeOH}-\mathrm{H}_{2} \mathrm{O}(1: 1)$ and $\mathrm{H}_{2} \mathrm{O}$ to give 288 crude extracts. All of these extracts were tested for their $\mathrm{XO}$ inhibitory activity to identify potential anti-gout agents. The assay was carried out at four different concentrations of extract ranging from $10-100 \mu \mathrm{g} / \mathrm{ml}$ (Table 2).

Of the extracts assayed, 188 extracts $(65.3 \%)$ demonstrated XO inhibitory activity at $100 \mu \mathrm{g} / \mathrm{ml}$, among which 46 $(24.5 \%)$ showed an inhibition rate greater than 50\%. Altogether, 168 extracts $(58.3 \%)$ were found to be active at a concentration of $50 \mu \mathrm{g} / \mathrm{ml}$, among which $21(12.5 \%)$ showed inhibition of more than $50 \%$. At $25 \mu \mathrm{g} / \mathrm{ml}, 146$ extracts $(50.7 \%)$ were active, and eight (5.5\%) showed an inhibition of over $50 \%$. Of the extracts assayed, $126(43.8 \%)$ displayed activity at $10 \mu \mathrm{g} / \mathrm{ml}$, including two $(1.6 \%)$ of over $50 \%$ inhibition. In total, $49\left[31 \mathrm{MeOH}, 15 \mathrm{MeOH}-\mathrm{H}_{2} \mathrm{O}(1: 1)\right.$, and three $\mathrm{H}_{2} \mathrm{O}$ ] extracts showed $\mathrm{IC}_{50}$ values below $100 \mu \mathrm{g} / \mathrm{ml}$. In general, the $\mathrm{MeOH}$ extracts were found to be more active than the $\mathrm{MeOH}-\mathrm{H}_{2} \mathrm{O}$ and $\mathrm{H}_{2} \mathrm{O}$ extracts.

The crude extracts possessing $\mathrm{XO}$ inhibitory activity with $\mathrm{IC}_{50}$ values less than $20 \mu \mathrm{g} / \mathrm{ml}$ were $\mathrm{MeOH}$ extracts of Artemisia vulgaris $\left(\mathrm{IC}_{50}, 14.7 \mu \mathrm{g} / \mathrm{ml}\right)$ and Caesalpinia sappan $\left(\mathrm{IC}_{50}, 14.2 \mu \mathrm{g} / \mathrm{ml}\right)$ from the Seven-Mountain area, Blumea balsamifera $\left(\mathrm{IC}_{50}, 6.0 \mu \mathrm{g} / \mathrm{ml}\right)$ from Lam Dong province, and Chrysanthemum sinense $\left(\mathrm{IC}_{50}, 5.1 \mu \mathrm{g} / \mathrm{ml}\right)$ from Khanh Hoa province and the $\mathrm{MeOH}-\mathrm{H}_{2} \mathrm{O}$ extract of Tetracera scandens from Khanh Hoa province $\left(\mathrm{IC}_{50}, 15.6 \mu \mathrm{g} / \mathrm{ml}\right)$. Although these plants are used in Vietnamese folk medicine to treat of rheumatism and inflammatory diseases, ${ }^{17)}$ this is the first report on their XO inhibitory activity.

The aerial part of $A$. vulgaris is widely used for the treatment of rheumatism and fever in Vietnam. The phytochemical studies on this plant species reported that it contains a number of flavonoids (e.g., apigenin, eriodictyol, kaempferol, luteolin) as the major constituents, together with monoterpenes, sesquiterpene lactones, and other compounds. ${ }^{18-20)}$ Flavonoids are well known antioxidants and attract a tremendous amount of interest among researchers as possible therapeutic agents for diseases mediated by free radicals. Flavonoids are also effective inhibitors of several enzymes including XO, cyclooxygenase, and lipooxigenase. ${ }^{21-23)}$ Thus, the putative therapeutic effects of $A$. vulgaris and its $\mathrm{XO}$ inhibitory activity are ascribed to its flavonoid constituents. Another Asteraceae plant, B. balsamifera, is also reported to contain a number of flavonoids inhibiting XO. ${ }^{21-25)}$

It is interesting to note that the wood of $C$. sappan possesses various biological activities such as antioxidative, antiinflammatory, hepatoprotective, cytotoxic, and hypoglycemic activity. Among the activities, the antioxidative activity is the most widely studied, and was attributed to the presence of phenolic compounds such as brazilin and flavanoids. ${ }^{26,27)}$ Two phenolic compounds isolated from C. sappan, 1', $4^{\prime}$ dihydro-spiro[benzofuran-3(2H), $3^{\prime}$-[3H-2]benzopyran]$1^{\prime}, 6^{\prime}, 6^{\prime}, 7^{\prime}$-tetrol and 3-[[4,5-dihydroxy-2-(hydroxymethyl)phenyl]methyl]-2,3-dihydro-3,6-benzofurandiol, were reported to inhibit XO. ${ }^{28)}$ Thus, the phenolic constituents may play an essential role in the inhibition of $\mathrm{XO}$ by $C$. sappan. Although all three extracts of $T$. scandens showed $\mathrm{XO}$ inhibitory activity, there are no scientific reports on their chemical constituents and biological activity. However, the presence of flavonoids such as derivatives of quercetin, kaempferol, apigenin, luteolin, and myricetin, have been 


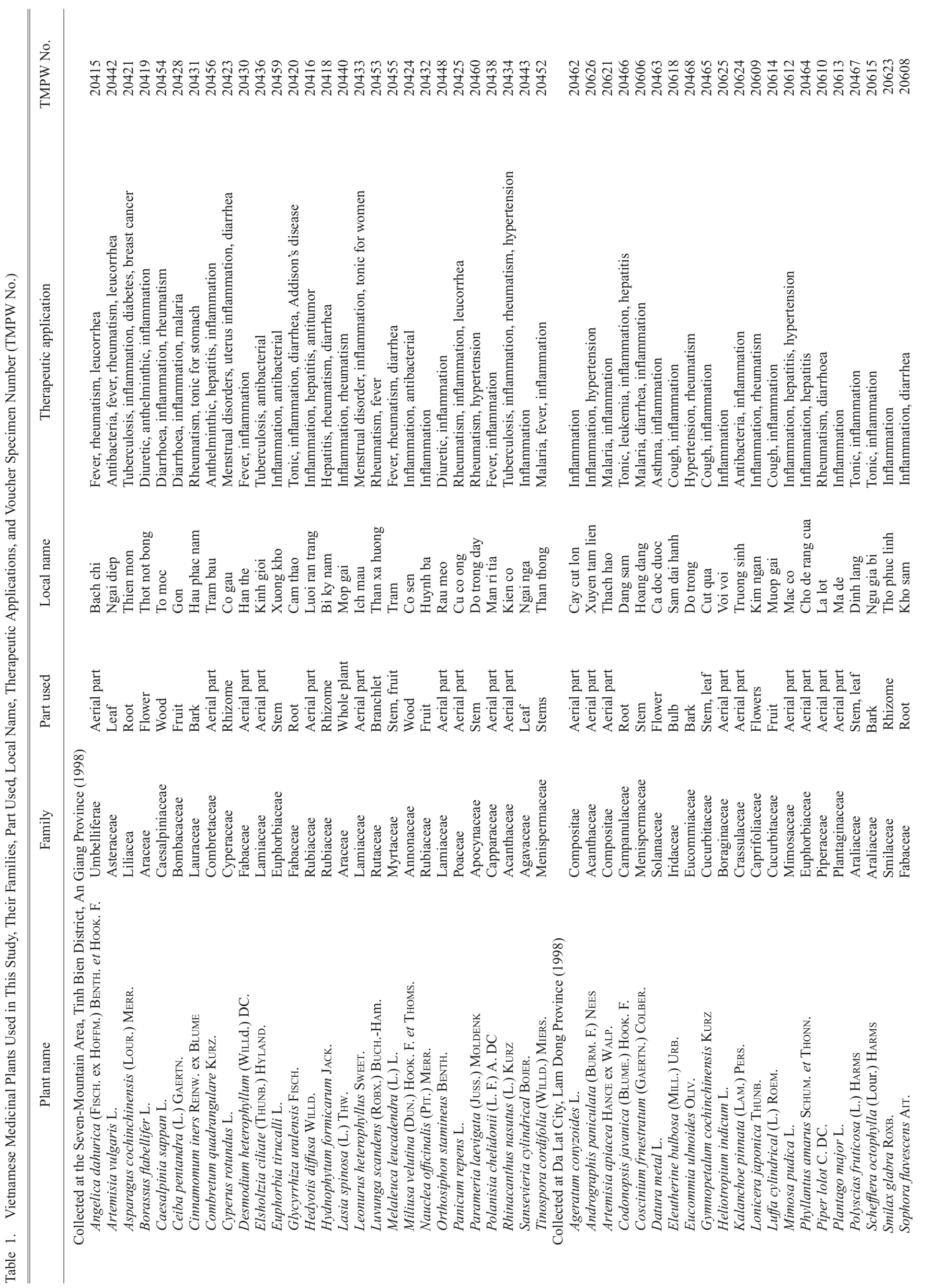




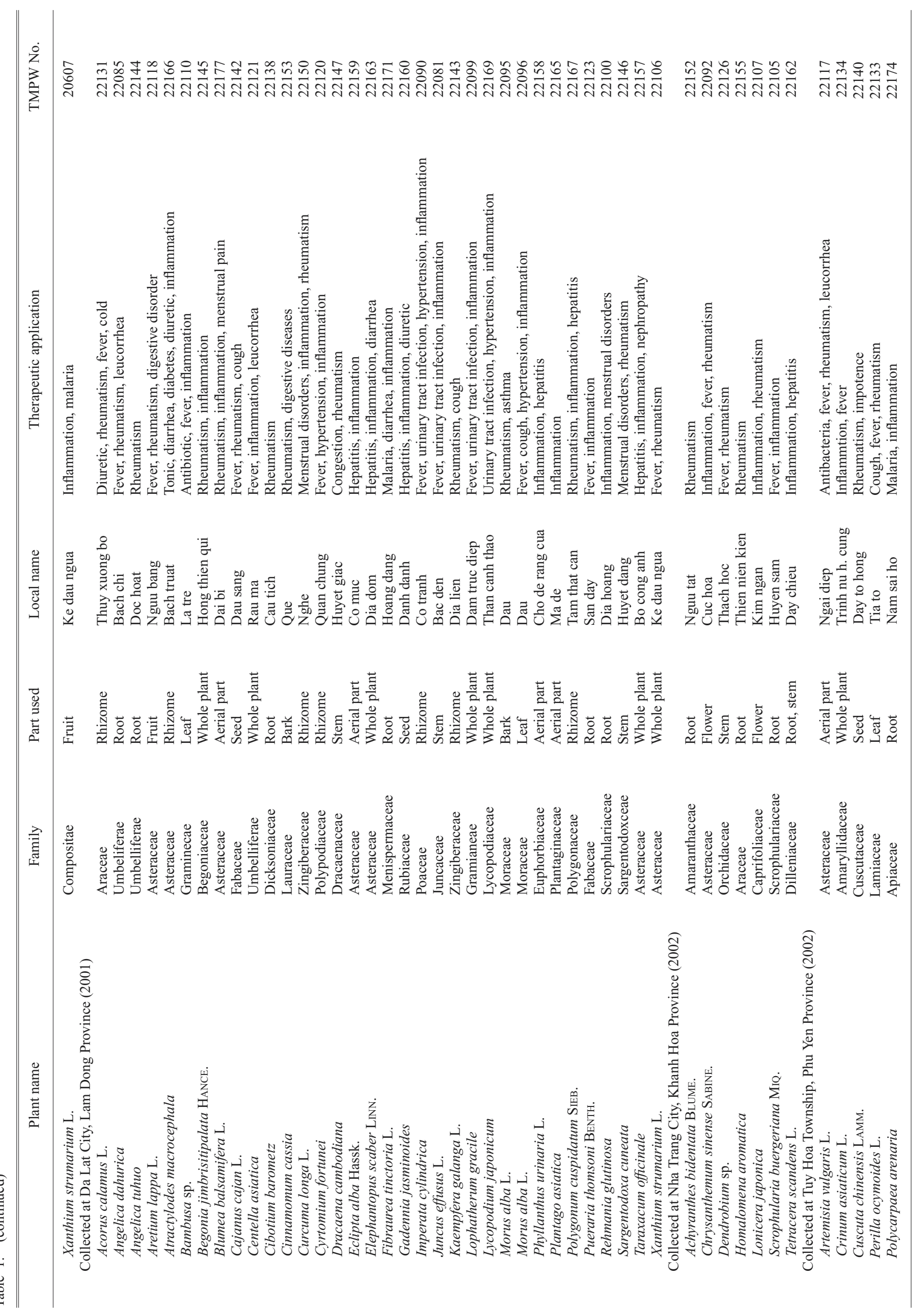




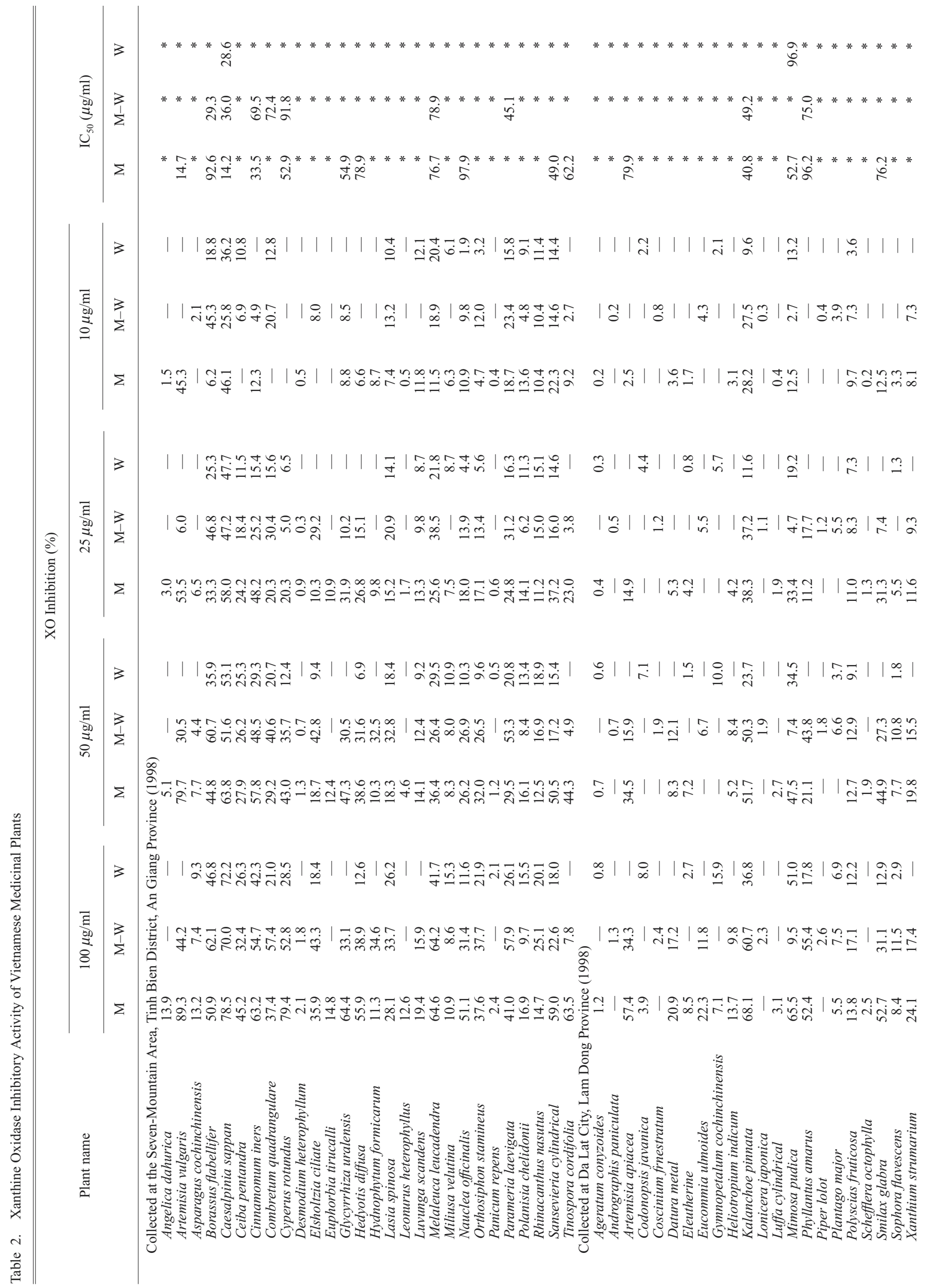




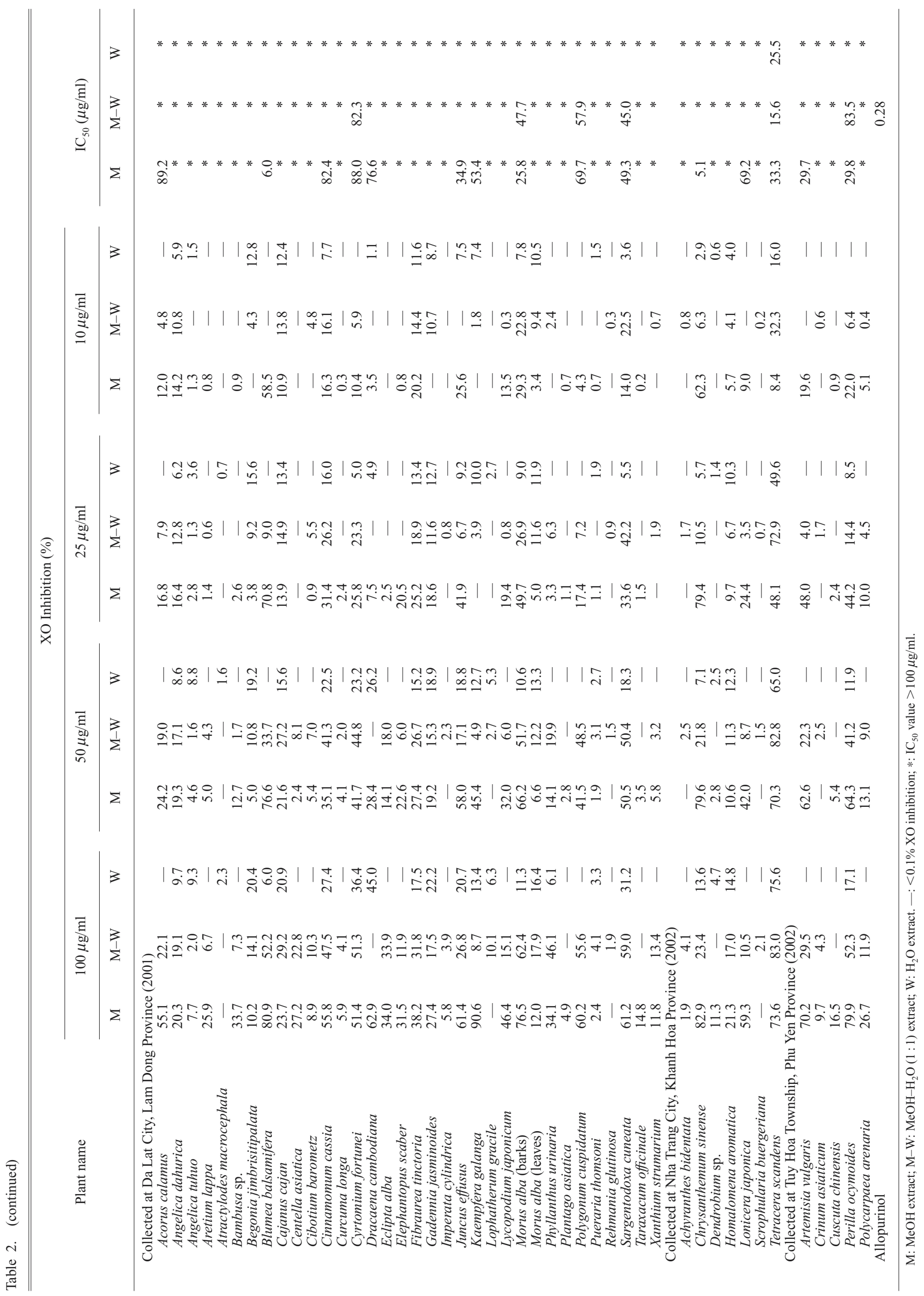




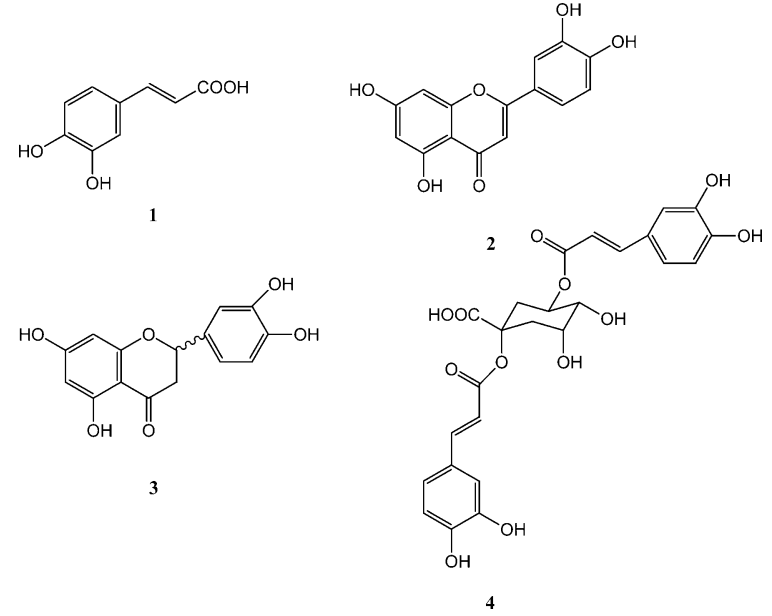

Fig. 1. Structures of the Compounds Isolated from the Flower of Chrysanthemum sinense

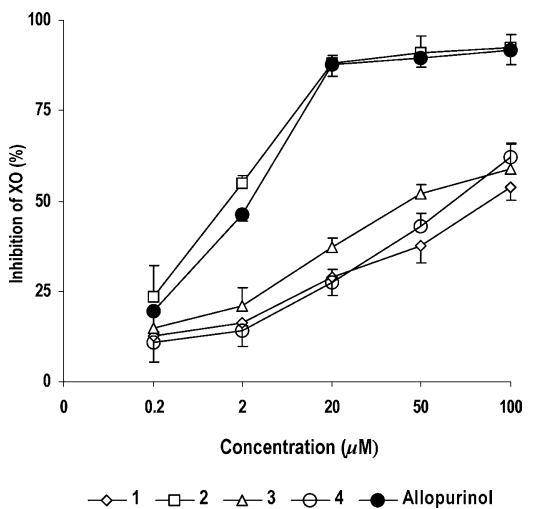

Fig. 2. Dose-Dependent XO Inhibition by Compounds $\mathbf{1}-\mathbf{4}$ and Allopurinol

The data represent the mean \pm S.D. of four determinations

reported together with the antioxidative and hepatoprotective activities in other Tetracera species. ${ }^{29-32)}$ Thus, the XO inhibitory activity of $T$. scandens also may be due to the presence of phenolic constituents.

The most active extract found in the present screening was the $\mathrm{MeOH}$ extract of the flower of $C$. sinense $\left(\mathrm{IC}_{50}\right.$, $5.1 \mu \mathrm{g} / \mathrm{ml}$ ), which is used for the treatment of rheumatism and inflammatory diseases. To date, no chemical constituents have been reported from $C$. sinense, and thus we carried out further investigation to isolate and identify the active constituents. The $\mathrm{MeOH}$ extract of the flower of $C$. sinense was subjected to silica gel column chromatography to give six fractions. Further separation and purification of the active fractions with reversed-phase preparative TLC led to the isolation of caffeic $\operatorname{acid}^{2)}(\mathbf{1})$, luteolin ${ }^{9)}(\mathbf{2})$, eriodictyol ${ }^{10)}(\mathbf{3})$, and 1,5-di-O-caffeoylquinic acid ${ }^{11)}$ (4) (Fig. 1). These compounds were examined for their XO inhibitory activity (Fig. 2). Among them, luteolin (2) displayed more potent inhibitory activity $\left(\mathrm{IC}_{50}, 1.3 \mu \mathrm{M}\right)$ than the positive control allopurinol $\left(\mathrm{IC}_{50}, 2.5 \mu \mathrm{M}\right)$, while the $\mathrm{IC}_{50}$ values of $\mathbf{1}$ and 4 were $85.3 \mu \mathrm{M}$ and $64.4 \mu \mathrm{M}$, respectively. The increase in XO inhibitory activity of $\mathbf{2}$ compared with $\mathbf{3}\left(\mathrm{IC}_{50}, 43.8 \mu \mathrm{M}\right)$ suggests the importance of the $\mathrm{C}_{2}-\mathrm{C}_{3}$ double bond in flavonoids for the activity.

In order to determine the inhibition mode of $\mathbf{2}$, further ki- netic studies were carried out. Lineweaver-Burk plots indicated 2 to be a competitive inhibitor, the same as allopurinol, with respect to the substrate, xanthine. The inhibition constant $\left(K_{\mathrm{i}}\right)$ of 2 was $0.92 \mu \mathrm{M}$, which was less than that of allopurinol $(1.88 \mu \mathrm{M})$. Further HPLC analysis of the crude extract of $C$. sinense suggested the most active constituent 2 to be the major constituent ( $106 \mu \mathrm{g} / \mathrm{mg}$ of extract). Thus, the traditional use of $C$. sinense for the treatment of rheumatism and inflammatory deseases in Vietnam might be attributable to the XO inhibitory activity of flavonoid constituents such as 2.

In conclusion, we have carried out a systematic investigation of Vietnamese medicinal plants for XO inhibitory activity. The results indicate a number of medicinal plants that may be useful for the treatment of hyperuricemia and gout, and provide the basis for further investigation on these medicinal plant species to isolate active constituents and drug development.

Acknowledgements This work was supported in part by a Grant-in-Aid for international Scientific Research (No. 13576027) from the Ministry of Education, Culture, Sports, Science and Technology, Japan. We thank Prof. Qui Kim Tran and Dr. Nhan Trung Nguyen for collecting and providing the Vietnamese medicinal plants.

\section{REFERENCES}

1) World Health Organization Regional Office for Western Pacific, Institute of Materia Medica, "Medicinal Plants in Viet Nam," Science and Technology Publishing House, Hanoi, 1998.

2) Chiang H. C., Lo Y. J., Lu F. J., J. Enz. Inhibit., 8, 61-71 (1994).

3) Owen P. L, Jhons T., J. Ethnopharmacol., 64, 149-160 (1999)

4) Oettl K., Reibnegger G., Biochim. Biophys. Acta, 1430, 387-395 (1999).

5) Ishibuchi S., Morimoto H., Oe T., Ikebe T., Inoue H., Fukunari A., Kamezawa M., Yamada T., Naka Y., Bioorg. Med. Chem. Lett., 11, 879-882 (2001).

6) Osada Y., Tsuchimoto M., Fukushima H., Takahashi K., Kondo S., Hasegawa M., Komoriya K., Eur. J. Pharmacol., 241, 183-188 (1993).

7) Cos P., Ying L., Calomme M., Hu J. P., Cimanga K., Van Poel B., Pieters L., Vlietinck A. J., Berghe D. V., J. Nat. Prod., 61, 71-76 (1998).

8) Noro T., Oda Y., Miyase T., Ueno A., Fukushima S., Chem. Pharm. Bull., 31, 3984-3987 (1983).

9) Ternai B., Markham K. R., Tetrahedron, 32, 565-569 (1976).

10) Wagner H., Chari V. M., Tetrahedron Lett., 21, 1799-1802 (1976).

11) Merfort I., Phytochemistry, 31, 2111-2113 (1992).

12) Kong L. D., Cai Y., Huang W. W., Cheng C. H. K., Tan R. X., J. Ethnopharmacol., 73, 199-207 (2000).

13) Sweeney A. P., Wyllie S. G., Shalliker R. A., Markham J. L., J. Ethnopharmacol., 75, 273-277 (2001).

14) Theoduloz C., Pacheco P., Hirschman G. S., J. Ethnopharmacol., 33, $253-255$ (1991)

15) Theoduloz C., Franco L., Ferro E., Hirschman G. S., J. Ethnopharmacol., 24, 179-183 (1988).

16) Gonzalez A. G., Bazzocchi I. L., Moujir L., Ravelo A. G., Correa M. D., Gupta M. P., J. Ethnopharmacol., 46, 25-29 (1995).

17) Do T. L., "Vietnamese Medicinal Plants," Medicine Publisher, Hanoi, 2001

18) Macro J. A., Sanz J. F., Hierro P. D., Phytochemistry, 30, 2403-2404 (1991).

19) Geissman T. A., Phytochemistry, 9, 2377-2381 (1970).

20) Lee S.-J., Chung H.-Y., Maier C. G., Wood A. R., Dixon R. A., Mabry T. J., J. Agric. Food Chem., 46, 3325-3329 (1998).

21) Hoorn D. E. C. V., Nijiveldt R. J., Leeuwen P. A. M. V., Hofman Z., M'Rabet L., Bont D. B. A. D., Norren K. V., Eur. J. Pharmacol., 451, 


$$
\text { 111-118 (2002). }
$$

22) Hayashi T., Sawa K., Kawasaki M., Arisawa M., Shimizu M., Morita N., J. Nat. Prod., 51, 345-348 (1988).

23) Ruangrungsi N., Tappayuthpijarn P., Tantivatana P., J. Nat. Prod., 44, $541-545$ (1981).

24) Barua N. C., Sharma R. O., Phytochemistry, 31, 4040 (1992).

25) Barua N. C., Sharma R. O., Thyagarajan G., Herz W., Govindan S. V., Phytochemistry, 18, 2003-2006 (1979).

26) Badami S., Moorkoth S., Rai S. R., Kannan E., Bhojraj S., Biol. Pharm. Bull., 26, 1534-1537 (2003).

27) Moon C.-K., Park K.-S., Kim S.-G., Won H.-S., Chung J.-H., Drug
Chem. Toxicol., 15, 81—91 (1992).

28) Safitri R., Tarigan P., Freisleben H. J., Rumampuk R. J., Murakami A., Biofactors, 19, 71-77 (2003).

29) Harrison L. J., Sia G.-L., Sim K.-Y., Planta Med., 60, 493-494 (1994).

30) Harborne J. B., Phytochemistry, 8, 419-423 (1969).

31) Kukongviriyapan V., Janyacharoen T., Kukongviriyapan U., Laupattarakasaem P., Kanokmedhakul S., Chantaranothai P., Phytother. Res., 17, 717-721 (2003).

32) Gurni A. A., Konig W. A., Kubitzki K., Phytochemistry, 20, 10571059 (1981). 